\title{
Study The Effect of Chamomile and Garcinia herbs on Obese Rats
}

\author{
${ }^{1}$ Mai M. Khafagy, ${ }^{2}$ Basma M. Samir \\ ${ }^{1}$ Assistant Prof.of Nutrition and Food Science, Faculty of Home Economics, \\ Menoufia University, ${ }^{2} \mathrm{Ph} . \mathrm{D}$ in nutrition, Suez Canal University
}

\begin{abstract}
:
This study aimed to investigate the effect of chamomile (Matricaria chamomilla), garcinia (Garcinia cambogia) and mixture of both on male obese rats. Thirty (30) adult male Sprague Dawley rats were divided into five groups. Group (1): Normal rats fed on basal diet as control negative (C-), Group (2): Control positive $(\mathrm{C}+)$ (untreated group). Group (3): Obese rats fed on basal diet and Chamomile (5\%). Group (4): Obese rats fed on basal diet and Garcinia (5\%). Group (5): Obese rats fed on basal diet and mixture of both (5\%). At the end of experiment, after 28 days of feeding, all serum samples were analyzed for biochemical parameters. Body weight gain, feed intake and feed efficiency ratio also calculated. Obesity led to a significant $(\mathrm{P} \leq 0.05)$ decrease in the level of HDL \& AST/ALT while a significant $(\mathrm{P} \leq 0.05)$ increase was recorded in TC, TG, VLDL, LDL, AI, U.A, Creatinine, Urea, GOT, GPT, ALP \& Glucose. Obese rats were fed on different diets and the results showed amarked improvement in all the different indicators.
\end{abstract}

Improvement was more pronounced for garcinia compared to chamomile diets, and the best group was recorded for the mix group, indicating a synergistic action. It is therefore recommended to use them as effective treatments in reducing the accumulation of harmful fat in the body and reducing weight.

Key words: Obesity- Chamomile - Garcinia. 


\section{Introduction:}

Chamomile (Matricaria chamomilla L.) is one of the Asteraceae family is an annual plant indigenous to Europe and Asia (Ortiz et al., 2016), possessing branched, erect, and smooth stems (Morales bozo et al., 2017). Its other names are chamomile or camomile, Italian camomilla, German chamomile, wild chamomile, Hungarian chamomile, (Mekonnen et al., 2016). German chamomile is useful for treatment of stomachache, irritable bowel syndrome, and insomnia.

It also has acaricidal properties. In several animal studies, anxiolytic, antimutagenic and cholesterol-lowering, wound healing, and antidiabetic properties for this plant were suggested. In in vitro studies, chamomile was demonstrated to possess modest antimicrobial and antioxidant properties and strong antiplatelet and anticarcinoma properties. It is able to cure skin lesions in colostomy patients and is beneficial for generalized anxiety disorders and anxiolytic activity in patients with mild to moderate generalized anxiety disorders (Miraj and Alesaeidi, 2016).

The chemical compounds of this plant are as follows: Apigenin, apigenin-7-Oglucoside, caffeic acid, chlorogenic acid, luteolin, and luteolin-7-O-glucoside, terpene bisabolol farnesene, chamazulene, flavonoids (including apigenin, quercetin, patuletin, and luteolin), and coumarin (Avonto et al., 2013).

Garcinia cambogia is an herbal product derived from the fruit of the Malabar tamarind tree (also called Garcinia gummi-gutta) native to India, Nepal and Sri Lanka (Bo et al., 2020). The fruit rind is used either as food preservative, flavoring agent, food-bulking agent or traditional medicine in many Asian countries (Semwal et al., 2015). Garcinia contains xanthones, benzophenones, amino acids and organic acids, of which hydroxy-citric acid (HCA) accounts for $10 \%-30 \%$ of the weight of garcinia fruit and $20 \%-60 \%$ of the extract (Bo et al., 2020).

Studies with different duration of administration and doses of Garcinia cambogia or its extract, were performed both in animals and humans with conflicting results. Favorable effects of Garcinia cambogia on glucose and lipid metabolism, as well as on appetite reduction, have been reported (Haber et al., 2018).

In animal studies, supplementation with HCA induced energy expenditure acceleration by the activation of the adiponectin AMPK signaling pathway (Li 
et al., 2019) or through the regulation of thyroid hormone levels (Han et al., 2016). HCA inhibits serotonin uptake leading to satiety and reduced food intake and down-regulates ATP-citrate lyase, increasing fat oxidation and decreasing de novo lipogenesis (Fassina et al., 2015).

This study aimed to investigate the possible benefical effect of garcinia and chamomile on obesity rats.

\section{Materials and Methods Materials:}

Chamomile (Matricaria chamomilla) and garcinia (Garcinia cambogia) were obtained dry from herb shop in Cairo, Egypt.

\section{Analytical methods:}

Protein, ash, fat, fibre and mineral contents were determined according to the method of AOAC, (2005) while total carbohydrates were estimated by difference. Hydroxy citric acid (HCA) in Garcinia combogia was determined by using HPLC apparatus according to Wodecki, et al., (1991) method. HCA was extracted by using phosphoric acid $(0.1 \% \mathrm{v} / \mathrm{v})$ from Garcinia dried fruits. The clear filtrate was injected into Helwellet Packared 1050 HPLC fitted with C18 column (250X $4.6 \mathrm{~mm})$. Ultraviolet (UV) detector set and quarter HP (series 1050). The column temperature was $55 \mathrm{C}^{\circ}$ throughout the analysis. Retention time of standard HCA was used to characterize HCA of Garcinia. A calibration curve of HCA was used to quantify the level of HCA in the fruit sample by the data analysis of HPLC apparatus. Antioxidant activity of sample extracts was studied through the evaluation of the free radicalscavenging effect on the 1, 1-diphenyl-2-picrylhydrazyl (DPPH) radical. The results were expressed as percentage of inhibition of the DPPH radical. Percentage of inhibition of the DPPH radical was calculated according to Alothman et al., (2009). The antioxidant (free radical scavenging activity, reducing power and lipid peroxidation inhibition) and antimicrobial (against bacteria and fungi) potential of Matricaria recutita L . (chamomile) extracts obtained by decoction was demonstrated. The characterization of the extracts highlighted dicaffeoyl-2,7-anhydro-3-deoxy-2-octulopyranosonic acid (diCDOA) and luteolin-O-glucuronide as the main phenolic compounds.The largest group of medically important compounds forming the essential oil are chamazulene, epi-[alpha]-bisabolol, [alpha]-bisabolol oxide, carvacrol, p-cymene, (E)-[beta]-ocimene, (Z)-[beta]- ocimene, (E,E)- 
farnesol, and en-yn-dicycloethers. Flavonoids, coumarins, hydroxycinnamic acids, mucilages and some other primary metabolites also have pharmacological effects. It contains $0.75 \%$ of a volatile oil. Mohammad,(2011)

\section{Animals:}

Thirty (30) adult male Sprague Dawley rats, average body weight (150 $\pm 10 \mathrm{~g})$ were used in this study.

\section{Methods:}

\section{High fat diet (HFD):}

The experimental (HFD) were prepared, containing 14\% protein from casein, $20 \%$ fat $(19 \%$ saturated fat $+1 \%$ unsaturated fat $), 5 \%$ cellulose, $3.5 \%$ salt mixture, $1 \%$ vitamin mixture, $10 \%$ sucrose, $0.25 \%$ choline chloride and the remainder was corn starch. The HFD used for 6 weeks was used to infect obese rats (Liu et al., 2004).

\section{Basal diet composition of tested rats:}

The basal diet was prepared according to Reeves et al.,(1993).it was consisted of $20 \%$ protin (casein ), $10 \%$ sucrose, $4,7 \%$ corn oil .2\%choline chloride, $1 \%$ vitamin mixture, $3.5 \%$ salt mixture and 5\%fiber(cellulose). The remainder was corn starch .

\section{Preparation of materials:}

All materials were milled to soft powder by using electric grinder and kept in dusky stoppered glass bottles in a cool and dry location till use according to Russo (2001).

\section{Induced obesity for rats:}

Rats were fed on HFD for 42 days before treating with herbs.

\section{Experimental design and animal groups:}

Rats were housed in wire cages under the normal laboratory condition, and were fed on basal diet for a week as an adaptation period. The rats were divided into 5 groups each of 6 rats. All groups of rats were housed in wire cages at 
room temperature $25^{\circ} \mathrm{C}$, and kept under normal healthy condition. Rats were divided into the following groups:

Group (1): Control negative group (-), in which normal rats were fed on basal diet.

Group (2): Control positive group (+), in which obese rats were fed on HFD.

Group (3): Obese rats fed on HFD supplemented with chamomile 5\%.

Group (4): Obese rats fed on HFD supplemented with Garcinia Cambogia 5\% diet.

Group (5): Obese rats fed on HFD supplemented with mixture of both 5\% diet (Chamomile : Garcinia Cambogia).

\section{Biological evaluation (BWG, FI and FER)}

During the experimental period (28days), the diet consumed was recorded every day and body weight was recorded every week. The body weight gain (B.W.G. g/day), feed efficiency ratio (F.E.R), and organ/ body weight were determined according to (Ellenberg, 1988) . Using the following equations:

B.W.G. $=$

$$
\text { (Final weight - Initial weight) }
$$

Grams gain in body weight

F.E.R. $=$

Grams feed consumed

\section{Determination of Biochemical Blood Parameters:}

Blood samples were collected after 12 hours fasting at the end of experiment using the abdominal aorta. The rats were scarified under ether anaesthesia. 
Blood samples were received into in clean dry centrifuge tubes, in which blood was left to clot at room temperature, and then centrifuged for 10 minutes at 3000 r.p.m to separate the serum. Serum was carefully aspirated and transferred into clean cuvette tubes and stored frozen at $20^{\circ} \mathrm{C}$ for biochemical analysis as described by Schermer (1967). All serum samples were analyzed for determination the following parameters:

Urea was determined according to the enzymatic method of Patton and Crouch (1977), creatinine was determined according to kinetic method of Henry (1974) and uric acid method was according to the enzymatic colorimetric test of Fossati and Prencipe (1980). Aspartate amino transferase (AST) and alanine amino transferase (ALT) were carried out according to the method of Yound (1975) and Tietz (1976). Alkaline phosphatase (ALP) was determined according to Belfield and Goldberg (1971). Total cholesterol (TC) was determined according to Allen (1974), and high density lipoprotein cholesterol (HDL-c) according to Lopez (1997). The calculation of low density lipoprotein cholesterol (LDL-c) was carried out according to the method of Lee and Nieman (1996) VLDL $=\frac{T C}{5} ; \quad L D L=T C-(V L D L+H D L)$, atherogenic index (AI) $\frac{\text { VLDL+LDL }}{\text { HDI }}$ was calculated according to Kikuchi et al., (1998) and triglyceride Fossati and Prencipe (1982). Serum glucose determined according to Kaplan (1984). Complete blood count carried out according to Fischback (1996).

\section{Statistical Analysis:}

The data were statistically analyzed using a computerized Costat Program by one way ANOVA using a Completely Randomized Factorial Design (SAS, 1988), when a significant mean effect was detected, the means were separated with the Duncan's Multiple Range Test. Differences between treatments at $\mathrm{P} \leq$ 0.05 were considered significant. The results are presented as mean $\pm \mathrm{SD}$.

\section{Results and Discussion:}

Data presented in table (1) showed that the effect of Chamomile, Garcinia cambogia and mixture of both on BWG, FI and FER of obese rats. It could be observed that the mean value of $(\mathrm{BWG})$ of control $(+)$ group was higher than control (-) group, being $2.50 \pm 0.054$ and $0.79 \pm 0.003 \mathrm{~g}$ respectively. The best (BWG) level showed for groups 5 (rats fed on basal diet containing $5 \%$ mixture of both herbs) when compared to control $(+)$ group. 
It could be noticed that the mean value of FI of control $(+)$ group was higher than control (-) group, being $20.83 \pm 0.002$ and $17.56 \pm 0.006 \mathrm{~g}$ respectively. The best (FI) level was showed for group 5 (rats fed on basal diet $+5 \%$ mixture of both) when compared to control (+) group.

Also, data of table (1) illustrate the mean value of (FER) of control ( + ) group was higher than control (-) group, being $0.120 \pm 0.001$ and $0.045 \pm 0.0002$ respectively. The best FER was shown for group 5 (rats fed on basal diet $+5 \%$ mixture of both) when compared to control (+) group.

In human research, Garcinia cambogia L. containing product decreased mean body weight (Chrubasik et al., 2008; Hasani et al., 2009), These results agree with those of (Suman et al.,2014).they reported that Garcinia cambogia L.administered rats showed a progressive decrease in body weight, Also these results agree with those of (Agyemang et al., 2013) They found that rats Matricaria chamomilla showed a progressive decrease in body weight.

Table (1): Effect of Matricaria chamomilla, Garcinia cambogia and mixture of both on body weight gain (BWG), feed intake (FI) and feed efficiency ratio (FER) of obese rats

\begin{tabular}{|c|c|c|c|}
\hline Groups & $\begin{array}{c}\text { BWG (g) } \\
\text { Mean } \pm \text { SD }\end{array}$ & $\begin{array}{c}\text { FI (g) } \\
\text { Mean } \pm \text { SD }\end{array}$ & $\begin{array}{c}\text { FER } \\
\text { Mean } \pm \text { SD }\end{array}$ \\
\hline G1: Control -ve & $0.79^{\mathrm{e}} \pm 0.003$ & $17.56^{\mathrm{e}} \pm 0.006$ & $0.045^{\mathrm{d}} \pm 0.0002$ \\
\hline G2: Control+ve & $2.50^{\mathrm{a}} \pm 0.054$ & $20.83^{\mathrm{d}} \pm 0.002$ & $0.120^{\mathrm{a}} \pm 0.001$ \\
\hline $\begin{array}{l}\text { G3: Chamomile } \\
(5 \%)\end{array}$ & $2.11^{\mathrm{b}} \pm 0.001$ & $22.11^{\mathrm{a}} \pm 0.002$ & $0.095^{\mathrm{b}} \pm 0.0003$ \\
\hline G4: Garcinia (5\%) & $1.96^{\mathrm{c}} \pm 0.005$ & $21.54^{\mathrm{b}} \pm 0.007$ & $0.091^{\mathrm{c}} \pm 0.0008$ \\
\hline $\begin{array}{l}\text { G5: Mixture of } \\
\text { both }(5 \%)\end{array}$ & $1.91^{\mathrm{d}} \pm 0.007$ & $21.22^{c} \pm 0.003$ & $0.090^{c} \pm 0.0014$ \\
\hline LSD & 0.044 & 0.008 & 0.0013 \\
\hline
\end{tabular}

Values of same letters in the same column indicate nonsignificant difference at ( $\mathrm{p} \leq$ $0.5)$.

Data presented in table (2) illustrate the effect of Chamomile, Garcinia and mixture of both on total cholesterol and triglycerides of obese rats. It could be observed that the mean value of total cholesterol (TC) of control $(+)$ group was higher than control (-) group, being $230 \pm 0.22$ and $84 \pm 0.24 \mathrm{mg} / \mathrm{dl}$ respectively. The best serum (TC) level was showed for groups 5 (rats fed on basal diet containing 5\% mixture of both) when compared to control $(+)$ group. 
It could be noticed that the mean value of triglycerides TG of control $(+)$ group was higher than control (-) group, being $226 \pm 0.12$ and $91 \pm 0.17 \mathrm{mg} / \mathrm{dl}$ respectively. The best serum (TG) level was showed for group 5 (rats fed on basal diet $+5 \%$ mixture of both) when compared to control $(+)$ group.

Rafraf et al., (2015) reported that Chamomile tea significantly decreased total cholesterol $(\mathrm{p}=0.001)$ and triglyceride $(\mathrm{p}<0.001)$ in T2DM patients.

Mahmoud and Amer (2013) indicted that oral administration of Garcinia Cambogia / Hydroxycitric acid induced reduction in TC and TG in treated rats.

Table (2): Effect of Matricaria chamomilla, Garcinia cambogia and mixture of both on total cholesterol (TC) and triglycerides (TG) of obese rats

\begin{tabular}{|l|c|c|}
\hline \multicolumn{1}{|c|}{ Parameters } & $\begin{array}{c}\text { TC } \\
\text { Mean } \pm \text { SD }\end{array}$ & $\begin{array}{c}\text { TG } \\
\text { Mean } \pm \text { SD }\end{array}$ \\
\hline G1: Control $-\mathrm{ve}$ & $84^{\mathrm{e}} \pm 0.24$ & $91^{\mathrm{e}} \pm 0.17$ \\
\hline G2: Control +ve & $230^{\mathrm{a}} \pm 0.22$ & $226^{\mathrm{a}} \pm 0.12$ \\
\hline \hline G3: Chamomile $(5 \%)$ & $112^{\mathrm{b}} \pm 0.26$ & $135^{\mathrm{b}} \pm 0.14$ \\
\hline \hline G4: Garcinia $(5 \%)$ & $92^{\mathrm{c}} \pm 0.23$ & $115^{\mathrm{c}} \pm 0.18$ \\
\hline \hline G5: Mixture of both $(5 \%)$ & $85^{\mathrm{d}} \pm 0.21$ & $94^{\mathrm{d}} \pm 0.13$ \\
\hline LSD & 0.42 & 0.27 \\
\hline
\end{tabular}

Values of same letters in the same column indicate nonsignificant difference at ( $\mathrm{p} \leq$ $0.5)$.

Data presented in table (3) show the effect of Chamomile, Garcinia and mixture of both on HDLc, LDLc, VLDLc \& AI of obese rats.

It could be observed that the mean value of (VLDLC) control $(+)$ group was higher than control (-) group, being $45.2 \pm 0.05$ and $18.2 \pm 0.02 \mathrm{mg} / \mathrm{dl}$ respectively. The best serum VLDLc was shown for group 5 (rats fed on basal diet $+5 \%$ mixture of both) when compared to control $(+)$ group.

It could be showed that the mean value of (HDLc) of control (-) group was higher than control $(+)$ group, being $49 \pm 0.31$ and $37 \pm 0.36 \mathrm{mg} / \mathrm{dl}$ respectively. The best serum HDLc was shown for group 5 (rats fed on basal diet containing $5 \%$ mixture of both herbs) when compared to control ( + ) group.

The same table indicated that the mean value of (LDLc) of control $(+)$ group was higher than control (-) group, being $147.8 \pm 0.06$ and $16.8 \pm 0.03 \mathrm{mg} / \mathrm{dl}$ respectively. The best serum LDLc was shown for group 5 (rats fed on basal diet $+5 \%$ mixture of both) when compared to control $(+)$ group. 
Also, data of table (4) observed that the mean value of (AI) of control $(+)$ group was higher than control (-) group, being 5.22 \pm 0.001 and $0.71 \pm 0.003$ respectively. The best AI was shown for group 5 (rats fed on basal diet $+5 \%$ mixture of both) when compared to control $(+)$ group.

Elsemelawy, (2019) indicted that levels of $10 \%$ and $20 \%$ chamomile show significant increase at the mean value of HDL and induced significant decrease in LDL and VLDL in diabetic rats.

Alkuraishy et al., (2014) indicted that Garcinia cambogia produced significant reductions in serum level of LDL and VLDL in hyperlipidemic rats.

Table (3): Effect of Matricaria chamomilla, Garcinia cambogia and mixture of both on (VLDLc), (HDLc), (LDLc) (mg/dl) and Atherogenic index (AI) of obese rats

\begin{tabular}{|c|c|c|c|c|}
\hline Groups & $\begin{array}{c}\text { VLDL } \\
(\mathrm{mg} / \mathrm{dl}) \\
\text { Mean } \pm \text { SD } \\
\end{array}$ & $\begin{array}{c}\text { HDL } \\
(\mathrm{mg} / \mathrm{dl}) \\
\text { Mean } \pm \text { SD } \\
\end{array}$ & $\begin{array}{c}\text { LDL } \\
(\mathrm{mg} / \mathrm{dl}) \\
\text { Mean } \pm \text { SD } \\
\end{array}$ & $\begin{array}{c}\text { AI } \\
\text { Mean } \pm \text { SD }\end{array}$ \\
\hline G1: Control -ve & $18.2^{\mathrm{e}} \pm 0.02$ & $49^{b} \pm 0.31$ & $16.8^{\mathrm{d}} \pm 0.03$ & $0.71^{\mathrm{d}} \pm 0.003$ \\
\hline G2: Control +ve & $45.2^{\mathrm{a}} \pm 0.05$ & $37^{\mathrm{d}} \pm 0.36$ & $147.8^{\mathrm{a}} \pm 0.06$ & $5.22^{\mathrm{a}} \pm 0.001$ \\
\hline $\begin{array}{l}\text { G3: Chamomile } \\
(5 \%)\end{array}$ & $27^{\mathrm{b}} \pm 0.12$ & $47^{\mathrm{c}} \pm 0.32$ & $38^{\mathrm{b}} \pm 0.05$ & $1.38^{\mathrm{b}} \pm 0.008$ \\
\hline $\begin{array}{l}\text { G4: Garcinia } \\
(5 \%)\end{array}$ & $23^{c} \pm 0.14$ & $49^{b} \pm 0.38$ & $20^{c} \pm 0.09$ & $0.88^{\mathrm{c}} \pm 0.005$ \\
\hline $\begin{array}{l}\text { G5: Mixture of } \\
\text { both }(5 \%)\end{array}$ & $18.8^{\mathrm{d}} \pm 0.09$ & $51^{\mathrm{a}} \pm 0.35$ & $15.2^{\mathrm{e}} \pm 0.07$ & $0.67^{\mathrm{e}} \pm 0.007$ \\
\hline LSD & 0.17 & 0.63 & 0.115 & 0.0099 \\
\hline
\end{tabular}

Values of same letters in the same column indicate nonsignificant difference at ( $\mathrm{p} \leq$ $0.5)$.

Results of table (4) show the mean value of serum uric acid (U.A), creatinine and urea $(\mathrm{mg} / \mathrm{dl})$ on obese rats fed on various diets.

It could be observed that the mean value of uric acid of control $(+)$ group was higher than control (-) group, being $6.94 \pm 0.003$ and $2.45 \pm 0.009 \mathrm{mg} / \mathrm{dl}$ respectively. Group 5 (basal diet containing 5\% mixture of both) recorded the best result as compared to control ( + ) group.

The same table (4) results illustrate that mean value of creatinine of control $(+)$ group was higher than control (-) group, being $1.62 \pm 0.006$ and $0.50 \pm 0.003$ $\mathrm{mg} / \mathrm{dl}$ respectively. In concern to creatinine the best treatment was recorded for 
the group 5 (rats fed on basal diet $+5 \%$ mixture of both) when compared to control (+) group.

It could be noticed that the mean value of urea of control $(+)$ group was higher than control (-) group, $58 \pm 0.11$ and $24 \pm 0.19 \mathrm{mg} / \mathrm{dl}$ respectively. Group 5 (rats fed on basal diet $+5 \%$ mixture of both) recorded the best result as compared to control (+) group.

El-Megid et al., (2017) found that Post-treatment of ethanol-administered rats with aqueous gamma-irradiated chamomile extract significantly decreased serum levels of urea, uric acid, and creatinine in rats with Alcohol Hepatonephrotoxicity.

Amin et al., (2011) investigated that Garcinia produce significant decrease in serum urea and creatinine in rats fed a diet with HFD.

Table (4): Effect of Matricaria chamomilla, Garcinia cambogia and mixture of both on uric acid (U.A), creatinine and urea (mg/dl) of obese rats

\begin{tabular}{|l||c|c|c||}
\hline \multicolumn{1}{|c|}{ Parameters } & $\begin{array}{c}\text { U.A } \\
(\mathbf{m g} / \mathbf{d l}) \\
\text { Gean } \pm \text { SD }\end{array}$ & $\begin{array}{c}\text { Creatinine } \\
(\mathbf{m g} / \mathbf{d l}) \\
\text { Mean } \pm \text { SD }\end{array}$ & $\begin{array}{c}\text { Urea } \\
(\mathbf{m g} / \mathbf{d l}) \\
\text { Mean } \pm \text { SD }\end{array}$ \\
\hline \hline G1: Control -ve & $2.45^{\mathrm{e}} \pm 0.009$ & $0.50^{\mathrm{d}} \pm 0.003$ & $24^{\mathrm{e}} \pm 0.19$ \\
\hline \hline G2: Control +ve & $6.94^{\mathrm{a}} \pm 0.003$ & $1.62^{\mathrm{a}} \pm 0.006$ & $58^{\mathrm{a}} \pm 0.11$ \\
\hline $\begin{array}{l}\text { G3: Chamomile } \\
(5 \%)\end{array}$ & $5.81^{\mathrm{b}} \pm 0.007$ & $0.71^{\mathrm{b}} \pm 0.004$ & $37^{\mathrm{b}} \pm 0.15$ \\
\hline \hline G4: Garcinia (5\%) & $5.34^{\mathrm{c}^{\mathrm{c}} \pm 0.004}$ & $0.70^{\mathrm{b}} \pm 0.007$ & $32^{\mathrm{c}} \pm 0.18$ \\
\hline $\begin{array}{l}\text { G5: } \text { Mixture of } \\
\text { both }(5 \%)\end{array}$ & $4.60^{\mathrm{d}} \pm 0.002$ & $0.57^{\mathrm{c}} \pm 0.009$ & $31^{\mathrm{d}} \pm 0.12$ \\
\hline LSD & 0.010 & 0.011 & 0.28 \\
\hline
\end{tabular}

Values of same letters in the same column indicate nonsignificant difference at ( $\mathrm{p} \leq$ $0.5)$.

Data of table (5) illustrate the effect of Chamomile, Garcinia cambogia and mixture of both on serum levels of AST, ALT, ALP enzymes \& (AST/ALT) ratio of obese rats.

It could be observed that the mean value of AST enzyme of control (+) group was higher than control (-) group, being $44 \pm 0.21$ and $25 \pm 0.22$ (U/L) respectively. The best treatment was observed for group 5 (basal diet containing $5 \%$ mixture of both) when compared to control $(+)$ group.

It could be noticed that the mean value of ALT enzyme of control $(+)$ group was higher than control (-) group, being $112 \pm 0.15$ and $27 \pm 0.13$ (U/L) 
respectively. The best treatment was observed for group 5 (basal diet containing $5 \%$ mixture of both) when compared to control $(+)$ group.

Data of the same table (5) show the mean value of ALP enzyme of control $(+)$ group was higher than control (-) group, being $419 \pm 0.12$ and $185 \pm 0.17$ (U/L) respectively. Group 5 showed the lowest mean value of ALP enzyme level as compared to control (+) group which and recorded the best result.

It could be noticed that the mean value of (AST/ALT) of control (-) group was higher than control $(+)$ group, being $0.93 \pm 0.002$ and $0.39 \pm 0.004$ respectively. The best treatment was observed for group 4, 5 when compared to control $(+)$ group.

Najla et al., (2012) reported that Matricaria chamomilla reduced alkaline phosphatase, aspartate aminotransferase and alanine amino transferase activities in diabetic rats.

Ateş et al., (2012) indicted that Garcinia cambogia extract decreased aspartate amino-transferase and alanine aminotransferase in rats fed high-lipid diet.

Table (5): Effect of Matricaria chamomilla, Garcinia cambogia and mixture of both on AST, ALT, AST/ALT and ALP (U/L) of obese rats

\begin{tabular}{|c|c|c|c|c|}
\hline Groups & $\begin{array}{c}\text { AST } \\
(\mathrm{U} / \mathrm{L}) \\
\text { Mean } \pm \text { SD } \\
\end{array}$ & $\begin{array}{c}\text { ALT } \\
(\mathbf{U} / \mathrm{L}) \\
\text { Mean } \pm \text { SD } \\
\end{array}$ & $\begin{array}{c}\text { AST/ALT } \\
\text { Mean } \pm \text { SD }\end{array}$ & $\begin{array}{c}\text { ALP } \\
(\mathrm{U} / \mathrm{L}) \\
\text { Mean } \pm \text { SD } \\
\end{array}$ \\
\hline G1: Control-ve & $25^{\mathrm{e}} \pm 0.22$ & $27^{\mathrm{c}} \pm 0.13$ & $0.93^{\mathrm{c}} \pm 0.002$ & $185^{\mathrm{d}} \pm 0.17$ \\
\hline G2: Control +ve & $44^{\mathrm{a}} \pm 0.21$ & $112^{\mathrm{a}} \pm 0.15$ & $0.39^{\mathrm{d}} \pm 0.004$ & $419^{\mathrm{a}} \pm 0.12$ \\
\hline $\begin{array}{l}\text { G3: Chamomile } \\
(5 \%)\end{array}$ & $32^{\mathrm{b}} \pm 0.25$ & $28^{\mathrm{b}} \pm 0.11$ & $1.16^{\mathrm{b}} \pm 0.003$ & $195^{\mathrm{c}} \pm 0.13$ \\
\hline $\begin{array}{l}\text { G4: Garcinia } \\
(5 \%)\end{array}$ & $27^{\mathrm{c}} \pm 0.21$ & $26^{\mathrm{d}} \pm 0.16$ & $1.19^{\mathrm{a}} \pm 0.005$ & $197^{\mathrm{b}} \pm 0.18$ \\
\hline $\begin{array}{l}\text { G5: Mixture of } \\
\text { both }(5 \%)\end{array}$ & $26^{\mathrm{d}} \pm 0.29$ & $25^{\mathrm{e}} \pm 0.18$ & $1.19^{\mathrm{a}} \pm 0.007$ & $185^{\mathrm{d}} \pm 0.19$ \\
\hline LSD & 0.43 & 0.27 & 0.008 & 0.29 \\
\hline
\end{tabular}

Values of same letters in the same column indicate nonsignificant difference at ( $\mathrm{p} \leq$ $0.5)$.

Data presented in table (6) show the effect of Chamomile, Garcinia cambogia and mixture of both on serum glucose of obese rats. It could be noticed that the mean value of glucose of control $(+)$ group was higher than control (-) group, being $292 \pm 0.11$ and $129 \pm 0.17(\mathrm{mg} / \mathrm{dl})$ respectively. The best serum glucose was observed for group 5 (basal diet containing 5\% mixture of both) when compared to control $(+)$ group. 
Najla et al., (2012) reported that Matricaria chamomilla reduced serum blood glucose in diabetic rats.

Sripradha, and Magadi (2015) showed that Garcinia cambogia extract along with high fat diet significantly decreased glucose in treated rats.

Table (6): Effect of Matricaria chamomilla, Garcinia cambogia and mixture of both on serum glucose ( $\mathrm{mg} / \mathrm{dl})$ of obese rats

\begin{tabular}{|l|c|}
\hline \multicolumn{1}{|c|}{ Parameters } & $\begin{array}{c}\text { Glucose } \\
\text { (mg/dl) } \\
\text { Mean } \pm \text { SD }\end{array}$ \\
\hline G1: Control -ve & $129^{\mathrm{e}} \pm 0.17$ \\
\hline G2: Control +ve & $292^{\mathrm{a}} \pm 0.11$ \\
\hline G3: Chamomile (5\%) & $150^{\mathrm{b}} \pm 0.15$ \\
\hline G4: Garcinia (5\%) & $136^{\mathrm{c}} \pm 0.13$ \\
\hline G5: Mixture of both (5\%) & $130^{\mathrm{d}} \pm 0.18$ \\
\hline LSD & 0.27 \\
\hline
\end{tabular}

Values of same letters in the same column indicate nonsignificant difference at $(\mathrm{p} \leq$ $0.5)$.

Data presented in table (7) show the effect of Chamomile, Garcinia cambogia and mixture of both on $\mathrm{Hb}, \mathrm{Ht}, \mathrm{RBC}, \mathrm{PLt}$ and $\mathrm{WBC}$ of obese rats.

It could be observed that the mean value of $(\mathrm{Hb})$ of control (-) group was higher than control $(+)$ group, being $19.80 \pm 0.008$ and $13.53 \pm 0.008 \mathrm{~g} / \mathrm{dl}$ respectively. The best $\mathrm{Hb}$ was shown for group 5 (rats fed on basal diet $+5 \%$ mixture of both) when compared to control $(+)$ group.

It could be showed that the mean value of $(\mathrm{Ht})$ of control (-) group was higher than control $(+)$ group, being $49 \pm 0.3$ and $41 \pm 0.2 \%$ respectively. The best $\mathrm{Ht}$ was shown for groups $4 \& 5$ when compared to control $(+)$ group.

The same table indicated that the mean value of red blood cells of control (-) group was higher than control (+) group, being $5.2 \pm 0.07$ and $3.5 \pm 0.04\left(10^{6} / \mu \mathrm{L}\right)$ respectively. The best RBC was shown for group 5 (rats fed on basal diet $+5 \%$ mixture of both) when compared to control $(+)$ group.

Also, data of table (8) observed that the mean value of (Plt) of control $(+)$ group was higher than control (-) group, being $602 \pm 0.7$ and $450 \pm 0.3\left(10^{3} / \mu \mathrm{L}\right)$ respectively. The best (Plt) was shown for group 5 (rats fed on basal diet $+5 \%$ mixture of both) when compared to control $(+)$ group.

It could be noticed that the mean value of (WBC) of control (-) group was 
higher than control $(+)$ group, being $10.2 \pm 0.04$ and $7.6 \pm 0.08\left(10^{3} / \mu \mathrm{L}\right)$ respectively. Groups $4 \& 5$ (recorded the best result as compared to control $(+)$ group.

Nwoye (2013) found that Matricaria Recutita extract increase Ht, Hb,WBC \& $\mathrm{RBC}$ in rats with ethanol intoxication.

Yonei et al., (2008) reported that Garcinia cambogia increased $\mathrm{Hb}, \mathrm{Ht}$ and $\mathrm{RBC}$ in healthy volunteers.

Table (7): Effect of Matricaria chamomilla, Garcinia cambogia and mixture of both on Hb, Ht, RBC, PLt and WBC of obese rats

\begin{tabular}{|c|c|c|c|c|c|}
\hline Groups & $\begin{array}{c}\text { Hb }(\mathrm{g} / \mathrm{dl}) \\
\text { Mean } \pm \text { SD }\end{array}$ & $\begin{array}{c}\text { Ht (\%) } \\
\text { Mean } \\
\pm \text { SD }\end{array}$ & $\begin{array}{c}\text { RBC } \\
\left(10^{6} / \mu \mathrm{L}\right) \\
\text { Mean } \\
\pm \text { SD } \\
\end{array}$ & $\begin{array}{c}\text { PLt } \\
\left(10^{3} / \mu \mathrm{L}\right) \\
\text { Mean } \\
\pm \text { SD } \\
\end{array}$ & $\begin{array}{c}\text { WBC } \\
\left(10^{3} / \mu L\right) \\
\text { Mean } \pm \text { SD }\end{array}$ \\
\hline G1: Control-ve & $19.80^{\mathrm{a}} \pm 0.008$ & $49^{c} \pm 0.3$ & $5.2^{\mathrm{a}} \pm 0.07$ & $450^{\mathrm{c}} \pm 0.3$ & $10.2^{b} \pm 0.04$ \\
\hline G2: Control+ve & $13.53^{\mathrm{c}} \pm 0.008$ & $41^{\mathrm{d}} \pm 0.2$ & $3.5^{\mathrm{b}} \pm 0.04$ & $602^{\mathrm{a}} \pm 0.7$ & $7.6^{\mathrm{d}} \pm 0.08$ \\
\hline $\begin{array}{l}\text { G3: Chamomile } \\
(5 \%)\end{array}$ & $18.70^{\mathrm{b}} \pm 0.009$ & $56^{\mathrm{b}} \pm 0.7$ & $4.7^{\mathrm{a}} \pm 0.08$ & $554^{\mathrm{b}} \pm 0.2$ & $9.9^{c} \pm 0.09$ \\
\hline $\begin{array}{l}\text { G4: Garcinia } \\
(5 \%)\end{array}$ & $19.10^{\mathrm{ab}} \pm 0.88$ & $58^{\mathrm{a}} \pm 0.6$ & $5.1^{\mathrm{a}} \pm 0.7$ & $441^{\mathrm{d}} \pm 0.5$ & $11.5^{\mathrm{a}} \pm 0.04$ \\
\hline $\begin{array}{l}\text { G5: Mixture of } \\
\text { both }(5 \%)\end{array}$ & $19.35^{\mathrm{ab}} \pm 0.006$ & $58^{\mathrm{a}} \pm 0.9$ & $5.2^{\mathrm{a}} \pm 0.07$ & $440^{\mathrm{d}} \pm 0.9$ & $11.5^{\mathrm{a}} \pm 0.01$ \\
\hline LSD & 0.72 & 1.09 & 0.58 & 1.05 & 0.11 \\
\hline
\end{tabular}

Values of same letters in the same column indicate nonsignificant difference at ( $\mathrm{p} \leq$ $0.5)$.

Data presented in table (8) illustrate the effect of Chamomile, Garcinia cambogia and mixture of both on Neutrophils, Lymphocytes, Monocytes, Eosinophils and Basophils $\left(10^{9} / \mathrm{L}\right)$ of obese rats.

It could be noticed that the mean value of Neutrophils of control (-) group was higher than control (+) group, being $4.29 \pm 0.007$ and $3.20 \pm$

0.003 respectively. The best Neutrophils was shown for groups $4 \& 5$ (when compared to control ( + ) group.

It could be observed that the mean value of Lymphocytes of control (-) group was higher than control $(+)$ group, being $4.73 \pm 0.005$ and $3.53 \pm 0.002$ respectively. The best Lymphocytes was shown for groups $4 \& 5$ when compared to control ( + ) group.

The same table revealed that the mean value of Monocytes of control (-) group was higher than control $(+)$ group, being $0.97 \pm 0.004$ and $0.72 \pm 0.002$ 
respectively. The best Monocytes was shown for groups $4 \& 5$ when compared to control (+) group.

Also, data of table (8) observed that the mean value of Eosinophils of control (-) group was higher than control (+) group, being $0.14 \pm 0.005$ and $0.11 \pm 0.001$ respectively. The best Eosinophils was shown for groups $4 \& 5$ when compared to control (+) group.

It could be noticed that the mean value of Basophils of control (-) group was higher than control $(+)$ group, being $0.06 \pm 0.001$ and $0.05 \pm 0.006$ respectively. Groups $4 \& 5$ recorded the best result as compared to control (+) group.

Amirghofran et al., (2000) reported that Chamomile increases lymphocytes in their study.

Table (8): Effect of Matricaria chamomilla, Garcinia cambogia and mixture of them on Neutrophils, Lymphocytes, Monocytes, Eosinophils and Basophils $\left(10^{9} / \mathrm{L}\right)$ of obese rats

\begin{tabular}{|c|c|c|c|c|c|}
\hline Groups & $\begin{array}{l}\text { Neutrophils } \\
\text { Mean } \pm \text { SD }\end{array}$ & $\begin{array}{c}\text { Lymphocytes } \\
\text { Mean } \pm \text { SD }\end{array}$ & $\begin{array}{l}\text { Monocytes } \\
\text { Mean } \pm \text { SD } \\
\end{array}$ & $\begin{array}{l}\text { Eosinophils } \\
\text { Mean } \pm \text { SD }\end{array}$ & $\begin{array}{c}\text { Basophils } \\
\text { Mean } \pm \text { SD }\end{array}$ \\
\hline $\begin{array}{l}\text { G1: Control - } \\
\text { ve }\end{array}$ & $\begin{array}{c}4.29^{\mathrm{b}} \pm \\
0.007 \\
\end{array}$ & $\begin{array}{c}4.73^{\mathrm{b}} \pm \\
0.005 \\
\end{array}$ & $\begin{array}{c}0.97^{\mathrm{b}} \pm \\
0.004 \\
\end{array}$ & $\begin{array}{c}0.14^{\mathrm{b}} \pm \\
0.005 \\
\end{array}$ & $\begin{array}{c}0.06^{\mathrm{ab}} \pm \\
0.001 \\
\end{array}$ \\
\hline $\begin{array}{l}\text { G2: } \\
\text { Control+ve }\end{array}$ & $\begin{array}{l}3.20^{\mathrm{d}} \pm \\
0.003\end{array}$ & $\begin{array}{c}3.53^{\mathrm{d}} \pm \\
0.002\end{array}$ & $\begin{array}{c}0.72^{\mathrm{d}} \pm \\
0.002\end{array}$ & $\begin{array}{l}0.11^{c_{1}} \\
0.001\end{array}$ & $\begin{array}{c}0.05^{\mathrm{b}} \pm \\
0.006\end{array}$ \\
\hline $\begin{array}{l}\text { G3: hamomile } \\
(5 \%)\end{array}$ & $\begin{array}{c}4.17^{\mathrm{c}} \pm \\
0.004 \\
\end{array}$ & $\begin{array}{c}4.59^{\mathrm{c}} \pm \\
0.008 \\
\end{array}$ & $\begin{array}{c}0.94^{\mathrm{c}} \pm \\
0.009 \\
\end{array}$ & $\begin{array}{c}0.14^{\mathrm{b}} \pm \\
0.007 \\
\end{array}$ & $\begin{array}{c}0.06^{\mathrm{ab}} \pm \\
0.009 \\
\end{array}$ \\
\hline $\begin{array}{l}\text { G4: Garcinia } \\
(5 \%)\end{array}$ & $\begin{array}{c}4.84^{\mathrm{a}_{1}} \pm \\
0.008\end{array}$ & $\begin{array}{c}5.34^{\mathrm{a}} \pm \\
0.004\end{array}$ & $\begin{array}{l}1.09^{\mathrm{a}} \pm \\
0.002\end{array}$ & $\begin{array}{c}0.16^{\mathrm{a}} \pm \\
0.008\end{array}$ & $\begin{array}{c}0.07^{\mathrm{a}} \pm \\
0.004\end{array}$ \\
\hline $\begin{array}{l}\text { G5: Mixture } \\
\text { of all }(5 \%)\end{array}$ & $\begin{array}{c}4.84^{\mathrm{a}} \pm \\
0.005 \\
\end{array}$ & $\begin{array}{c}.34^{\mathrm{a}} \pm \\
0.006 \\
\end{array}$ & $\begin{array}{l}1.09^{\mathrm{a}} \pm \\
0.009 \\
\end{array}$ & $\begin{array}{c}0.16^{\mathrm{a}} \pm \\
0.006 \\
\end{array}$ & $\begin{array}{c}0.07^{\mathrm{a}} \pm \\
0.001 \\
\end{array}$ \\
\hline LSD & 0.010 & 0.0098 & 0.011 & 0.011 & 0.009 \\
\hline
\end{tabular}

Values of same letters in the same column indicate nonsignificant difference at ( $\mathrm{p} \leq$ $0.5)$. 


\section{References:}

Agyemang, K.; Han, L.; Liu, E.; Zhang, Y. Wang,T.; and Gao, X.;( 2013): Recent advances in Matricaria chamomilla Anti-Obesity Research: 187-198.

Alkuraishy, H. M.; Algareeb, A. I.; Albuhadilly, A. K. and ALmgoter, B. M. (2014): Potential additive effects of Garcinia cambogia on atorvastatin treated hyperlipidemic patients: randomized crossover clinical study. International Journal of Advances in Medicine, 1(3): 189.

Allen, C.C. (1974): Cholesterol enzymatic colorimetric method. J. Clin. Chem., (20): 470 .

American Institute of Nutrition (AIN) (1993): Purified diet for laboratory rodent; final report. J. Nutrition, 123:1939-1951.

Amin, K. A.; Kamel, H. H. and Abd Eltawab, M. A. (2011): Protective effect of Garcinia against renal oxidative stress and biomarkers induced by high fat and sucrose diet. Lipids in Health and Disease, 10(1): 6.

Amirghofran, Z.; Azadbakht, M. and Karimi, M. H. (2000): Evaluation of the immunomodulatory effects of five herbal plants. Journal of Ethnopharmacology, 72(1-2): 167-172.

Alothman, M.; Bhat R. and Karim, A. A. (2009): Antioxidant capacity and phenolic content of selected tropical fruits from Malaysia, extracted with different solvents. Food Chemistry, $115,785-788$.

AOAC, 2005. Official Methods of the Association of Official Analytical Chemists 18th Ed. Washington, D.C., USA.

Ateş, A.; Esen Gürsel, F.; Bilal, T. and Altıner, A. (2012): Effect of dietary Garcinia cambogia extract on serum lipid profile and serum enzymes in rats fed high-lipid diet. Iranian Journal of Veterinary Research, 13(1): 1-7.

Avonto, C.; Wang, M.; Chittiboyina, A. G.; Avula, B.; Zhao, J. and Khan, I. A. (2013): Hydroxylated bisabolol oxides: Evidence for secondary oxidative metabolism in Matricaria chamomilla. Journal of Natural Products, 76(10): 1848-1853.

Belfield, A. and Goldberg, D.M. (1971): Alkaline phosphatase colorimetric method. J. of Enzyme, (12):561. 
Bo, S.; Fadda, M.; Fedele, D.; Pellegrini, M.; Ghigo, E. and Pellegrini, N. (2020): A critical review on the role of food and nutrition in the energy balance. Nutrients, 12(4): 1161.

Chrubasik, C.; Maier, T.;Dawid ,C.; Torda, T.; Schieber , A.; and Hofmann ,T. ;(2008): An observational study and quantification of the actives in a supplement with Garcinia cambogia used for weight reduction. Phytother .Res.;22(7):913-918.

El-Megid, A.; Mohamed, H. M.; Abdul Azeem, A. M. El-Shahat, A. N. and Mekawey, H. M. S. (2017): Identification of the therapeutic effects of gamma-irradiated chamomile aqueous extract against alcohol induced hepato-nephrotoxicity in rats. Egyptian Journal of Radiation Sciences and Applications, 30(1): 53-61.

Elsemelawy, S. A. (2019): Antidiabetic and Antioxidative Activity of Chamomile (Matricaria chamomilla L.) Powder on Diabetic Rats. Journal of Specific Education Studies and Research (2):1.

Ellenberg, H.; (1988): Vegetation ecology of Central Europe (4th ed.). Cambridge, UK Cambridge University Press.

Fassina, P.; Scherer Adami, F.; Zani, V. T.; Kasper Machado, I. C.; Garavaglia, J.; Quevedo Grave, M. T. and Morelo Dal Bosco, S. (2015): El efecto de la Garcinia cambogia como coadyuvante en el proceso de perdida de peso. Nutrición Hospitalaria, 32(6): 24002408 .

Fischback, F.T. (1996): A manual of Laboratory and Diagnosistic Tests. $5 \underline{\text { th }}$ Ed., 31-120.

Fossati, P. and Prencipe, L. (1982): Triglyceride enzymatic colorimetric method. J. Clin. Chem., (28): 2077.

Fossatti, P. and Prencipe, L. (1980): Enzymatic colorimetric test of uric acid. J. Clin. Chem., 28:227.

Haber, S. L.; Awwad, O.; Phillips, A.; Park, A. E. and Pham, T. M. (2018): Garcinia cambogia for weight loss. The Bulletin of the American Society of Hospital Pharmacists, 75(2): 17-22.

Han, N.; Li, L.; Peng, M. and Ma, H. (2016): ( ) Hydroxycitric acid nourishes protein synthesis via altering metabolic directions of amino acids in male rats. Phytotherapy Research, 30(8): 1316-1329. 
Hasani,R.S.; Nayebi ,N.; Larijani ,B.; and Abdollahi ,M.; (2009): A systematic review of the efficacy and safety of herbal medicines used in the treatment of obesity. World $\mathrm{J}$ Gastroenterol, 15(25):3073-3085.

Henry, R.J. (1974): Clinical Chemistry Principles and Techniques. 2nd Ed., Harper and Publishers, NewYork. Philadelphia.

Kaplan, L.A. (1984): Clinical Chemistry. The C.V. Mosby Co. St Louis. Toronto. Princeton, 1032-1036.

Kikuchi, H.; Onodera, N.; Matsubara, S., Yassudo, E.; Chonan,O.; Takahashi, R. and Ishikawa, F. (1998): Effect of soy milk on lipid metabolism in aged ovariectomized rats. Bioscience, Biotechnology and Biochemistry, 62(9): 1688 - 1692.

Lee, R. and Nieman, D. (1996): Nutritional Assessment.2nd Ed., Mosby, Missouri, USA.

Li, L.; Zhang, H.; Yao, Y.; Yang, Z. and Ma, H. (2019): (-)-Hydroxycitric acid suppresses lipid droplet accumulation and accelerates energy metabolism via activation of the adiponectin-ampk signaling pathway in broiler chickens. Journal of Agricultural and Food Chemistry, 67(11): 3188-3197.

Liu, M.; Shen, L.; Liu, Y.; Woods, S. C.; Seeley, R. J.; D'Alessio, D. and Tso, P. (2004): Obesity induced by a high-fat diet downregulates apolipoprotein A-IV gene expression in rat hypothalamus. American Journal of Physiology-Endocrinology and Metabolism, 287(2): 366-370.

Lopez, M.F. (1997): HDL- Cholesterol colorimetric method. J. Clin. Chem., (23): 282-289.

Mahmoud, G. S. and Amer, A. S. (2013): Effect of natural extract of hydroxycitric acid on lipid profile, Liver and testes of adult male rats. AAMJ, 11(1).

Mekonnen, A.; Yitayew, B.; Tesema, A. and Taddese, S. (2016): In vitro antimicrobial activity of essential oil of Thymus schimperi, Matricaria chamomilla, Eucalyptus globulus, and Rosmarinus officinalis. International Journal of Microbiology.

Miraj, S. and Alesaeidi, S. (2016): A systematic review study of therapeutic effects of Matricaria recuitta chamomile (chamomile). Electronic Physician, 8(9): 3024. 
Morales Bozo, I.; Ortega Pinto, A.; Rojas Alcayaga, G.; Aitken Saavedra, J. P.; Salinas Flores, O.; Lefimil Puente, C. and Urzúa Orellana, B. (2017): Evaluation of the effectiveness of a chamomile (Matricaria chamomilla) and linseed (Linum usitatissimum) saliva substitute in the relief of xerostomia in elders. Gerodontology, 34(1): 42-48.

Mohammad, Sh. M.(2011):Study on Cammomile (Matricaria chamomilla L.) usage and farming." Advances in Environmental Biology, p. 14-46.

Najla, O. A.; Olfat, A. K.; Kholoud, S. R.; Enas, N. D. and Hanan, S. A. (2012): Hypoglycemic and biochemical effects of Matricaria chamomilla leave extract in streptozotocin-induced diabetic rats. J Health Sci., 2(5): 43-48.

Nwoye, L. O. (2013): Protective and therapeutic effects of Chamomilla recutita extract on subacute ethanol intoxication in white albino rats. African Journal of Biotechnology, 12(18).

Ortiz, M. I.; Fernández-Martínez, E.; Soria-Jasso, L. E.; Lucas-Gómez, I.; Villagómez-Ibarra, R.; González-García, M. P. and SalinasCaballero, M. (2016): Isolation, identification and molecular docking as cyclooxygenase (COX) inhibitors of the main constituents of Matricaria chamomilla L. extract and its synergistic interaction with diclofenac on nociception and gastric damage in rats. Biomedicine \& Pharmacotherapy, 78: 248-256.

Patton, C.J. and Crouch, S.R. (1977): Enzymatic determination of urea. J. Anal. Chem., 49: 464- 469.

Rafraf, M.; Zemestani, M. and Asghari-Jafarabadi, M. (2015): Effectiveness of chamomile tea on glycemic control and serum lipid profile in patients with type 2 diabetes. Journal of Endocrinological Investigation, 38(2): 163-170.

Reeves, P. G.; Nielson, F. H. and Fahmy, G. C. (1993): Reports of the American Institute of Nutrition, Adhoc Wiling Committee on reformulation of the AIN 93. rodent diet. J. Nutri., 123: 1939- 1951

Russo, E. (2001): Handbook of Psychotropic Herbs: A Scientific Analysis of Herbal Remedies for Psychiatric Condition. The Howrth Herbal Press, Inc.

SAS (1988): SAS/STAT User's Guide, Release 6.03. Cary, North Carolina: SAS Institute. 
Schermer, S. (1967): The Blood Morphology of Laboratory Animal. Longmans, Printed in Great Britain, Green and Co. L.T.d.

Semwal, R. B.; Semwal, D. K.; Vermaak, I. and Viljoen, A. (2015): A comprehensive scientific overview of Garcinia cambogia. Fitoterapia, 102: 134-148.

Suman, S.A.; Omre ,P.K.; Sandhya, M.; and Mohan, C.; (2014): Garcinia cambogia L. a miracle plant. Ind. J. Sci. Res, 4 (1): 46-52.

Sripradha, R. and Magadi, S. G. (2015): Efficacy of Garcinia cambogia on body weight, inflammation and glucose tolerance in high fat fed male wistar rats. Journal of Clinical and Diagnostic Research: JCDR, 9(2): BF01.

Tietz, N.W. (1976): Fundamentals of Clinical Chemistry. Philadelphia. B. W. Standers, P. 243.

Wodecki, Z. J.; Torlop, Z. and Slebioda, M. (1991):Chromatographic Separation of Citric acid for monitoring the mould process. J. Chrom., 8: 302-305.

Yonei, Y.; Takahashi, Y.; Hibino, S.; Watanabe, M. and Yoshioka, T. (2008): Effects on the human body of a dietary supplement containing L-carnitine and Garcinia cambogia extract: A study using double-blind tests. Journal of Clinical Biochemistry and Nutrition, 42(2): 89-103.

Yound, D.S. (1975): Determination of GOT. J. Clin. Chem., 21: 1- 6. 


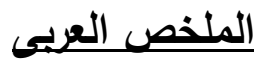

\section{دراسة تأثير أعثاب البابونج والجارسينيا على الفئران البيضاء المصابة بالسمنة}

يهدف هذا البحث إلى تقييم تأثنير أعثاب البابونج (كاموميل) والجارسينيا والخليط منهما علي ذكور الفئران المصابة بالسمنة. تم استخدام ثلاثثن فأر من الذكور البالغين سبراغ الباغن داولي وتغذيتهم على نظام غذائى عالى الدهون لمدة rأ يوما ثم تقسيمهم إلى خمس مجموعات. مجموعة (1): وهي المجموعة

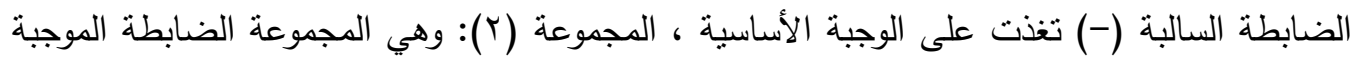

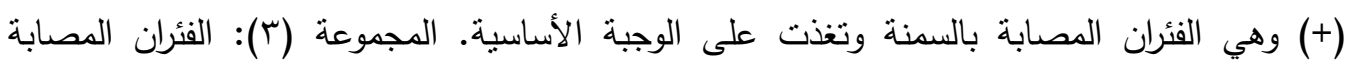

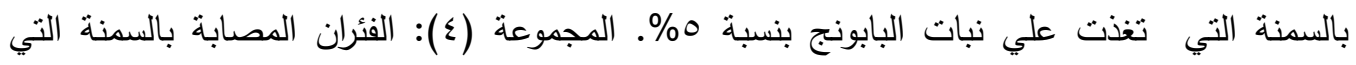

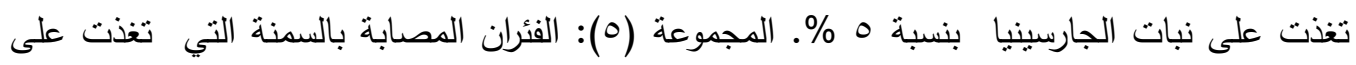
الاثثين معا بتركيز 0\%

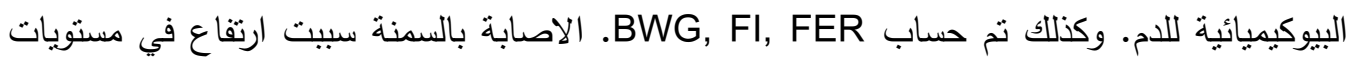
الجلوكوز واليوريا والكرياتينين واليوريك اسيد و AST و ALT و ALP ومستوى الكوليسترول الكلي

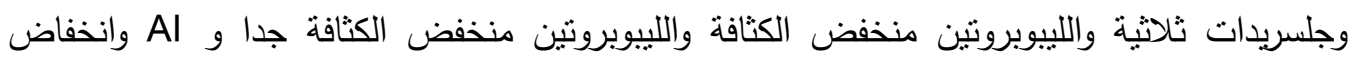
مستويات الليبروتين مرتفع الكثافة و AST/ALT في الفئران المصابة بالسمنة وتحسنت النتائج باستخدام

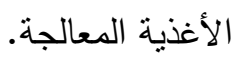
لوحظ أن التحسن كان اكبر فى حالة غذاء الجارسينيا بالمقارنة بغذاء الكاموميل وأحسن المعاملات كانت

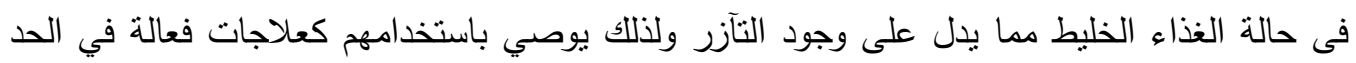

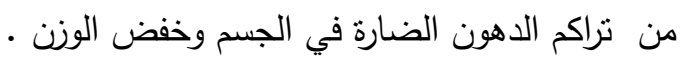

$$
\text { الكلمات المفتاحية: السمنة - البابونج - الجارسينيا. }
$$

